\title{
ASSESSMENT OF FERTILITY STATUS OF SOILS UNDER LAND USE TYPES IN EGBEMA AREA, IMO STATE, NIGERIA
}

\section{Chikere-Njoku C.}

Department of Soil Science and Environment, Imo State University, Owerri, P.M.B 2000, Nigeria

E-mail: Chikerenjoku@gmail.com

\begin{abstract}
The study was conducted to investigate fertility status under four different land use types (oil palm plantation, pineapple orchard, cassava cultivated land and fallow land use system) in Umuekem, Ohaji/Egbema of Imo State, Nigeria. Composite samples were collected from various depths $(10-15 \mathrm{~cm}, 15-30 \mathrm{~cm}, 30-45 \mathrm{~cm})$ across these land use patterns and analyzed in the laboratory using the standard procedure. Data generated were subjected to statistical analysis. Results obtained showed significant differences $(p 20.05)$ in silt-clay ratio, bulk density, total porosity, water holding capacity, soil pH, organic carbon, available phosphorus, TN and ECEC across the four land use types studied. The soils were predominantly loamy sand surface and sandy clay loam in the subsoil exception of pineapple orchard with sandy loam topsoil over sandy clay loam subsoil. The silt clay ratio (SCR) showed ranges of 0.10-0.30, 0.10-0.36, 0.07 0.30, and 0.06- 0.20 in land use types of oil palm plantation, pineapple orchard, cassava cultivated land and fallow land respectively. The bulk density ranged of $\left(1.61-1.77 \mathrm{~g} / \mathrm{cm}^{3}\right)$ for oil palm, $\left(1.34-1.58 \mathrm{~g} / \mathrm{cm}^{3}\right)$ for pineapple $\left(1.42-1.49 \mathrm{~g} / \mathrm{cm}^{3}\right)$ cassava and $\left(1.45-1.48 \mathrm{~g} / \mathrm{cm}^{3}\right)$ in forest land use system. The soils of the four land use types were generally acidic. The mean values of soil $\mathrm{pH}\left(\mathrm{H}_{2} \mathrm{O}\right)$ were oil palm plantation (5.11), pineapple orchard (5.03), cassava cultivated land (5.35) and fallow land (5.40). The soil $\mathrm{pH}$ recorded low variation in all the land use types. The organic carbon and total nitrogen recorded high variation $(>52.57 \%<85.67 \%$, $>79.19$ <95.77) in all the different land use types. Calcium-magnesium ratio (Ca: $\mathrm{Mg}$ ) recorded high variation (37.36\%) in forest land use system, low variation (18.77\%) in pineapple orchard and moderate in cassava (27.51\%) and oil palm plantation (28.23). The low Ca: Mg ratio inhibits uptake and causes Ca deficiency thereby resulting in low fertility status of the soil. $C: P$ recorded high variation ( $\geq 53.77 \% \leq 77.73 \%)$ in all the studied land use types. O.C correlated positively and highly significant with available phosphorus, ECEC and T.N. The findings also indicated that bulk density correlated positively with ECEC and percentage base saturation. It is recommended that land use approach should be adopted for effective and sustainable management of the soil fertility.
\end{abstract}

Keywords: Fertility status, Soils, Land use types

https://dx.doi.org/10.4314/jafs.v17i2.1

Journal of the Faculty of Agriculture and Veterinary Medicine, Imo State University Owerri website: www ajol.info 


\section{INTRODUCTION}

Soil fertility is one of the important and essential components of a sustainable agricultural system in the tropical climates. The fertility status of the soil is a subject of soil characteristics especially physical and chemical property of the soil (Badalikova and Hruby, 2016). The tropics is faced with a two dimensional problems of declining per capita production and progressive deterioration of the environment. Importantly also, is the high spatial variability in the physicochemical and morphological characteristics of soils implying that different soils respond differently to land use types and management options. Continuous cultivation and indiscriminate deforestation through the use of fuel wood as source of alternative energy are attributed to the main source of declining per capita productivity of soils and fertility status especially in the rain forest zone (Chude et al., 2011, Osuji et al., 2011, Hassan et al., 2016).

Land use can be defined as the human activities which are directly related to land, making use of its resources (FAO, 2016). In other words, it involves different land use types of which land is put. In Nigeria, especially south eastern agro-ecological zone, soil is subjected to many uses most of which are conflicting. However, inappropriate use of land has led to decline in soil quality for agricultural and non-agricultural purposes. It has been demonstrated around the world that low-input agriculture, practically in the absence of appropriate conservation practice leads to land degradation (IITA, 1995).

Land degradation is a consequence of mismanagement of land that results frequently from a mismatch between land quality and land use (Donahue et al., 1990). Earlier studies had emphasized the negative effect of land use on soil fertility status, for example Nsokpo and Ibanga (2001) examined the impact of land use systems on the fertility status of an ultisols in the humid forest zone of southeastern Cameroon, and their results showed that, land use types significantly affected the fertility status of the soil.

According to Nsokpo and Ibanga (2001), soil pH, total $\mathrm{N}$, organic carbon, available P., exchangeable calcium, exchangeable aluminum and ECEC, all deferred with land use patterns. Alves (2002) and Chude et al, (2011) stated in their findings that land use changes in tropical ecosystems could cause significant modifications in soil properties such as reduced fertility and land degradation.

The most prevalent land use types in Umuekem of Ohaji/Egbema Local Government Area, Imo State include oil palm plantation, cassava cultivated land, pineapple orchard and fallowed land (forests). There seems to be little or no information on the effect of these land use patterns on soil physico-chemical properties, hence food security. It therefore becomes necessary to assess the effect of land use systems on physical and chemical properties of soil in the areas as to determine its fertility status. 


\section{MATERIALS AND METHODS}

\section{Study Area}

The study area is Umuekem community, Ohaji/Egbema, Local Government Area of Imo State, Nigeria. It lies within latitude $5^{0} 41^{\prime}$ and $5^{0} 31^{\prime} \mathrm{N}$ and longitude $6^{0} 53^{\prime}$ and $7^{0} 35^{\prime} \mathrm{E}$. The study area is located within the humid tropical climate with a mean annual rainfall range of 2000 to $2,250 \mathrm{~mm}$. The mean annual temperature varies between $26^{\circ} \mathrm{C}$ to $32^{\circ} \mathrm{C}$ and relative humidity varies with seasons from $80-90 \%$ in the rainy season while $60-80 \%$ relative humidity is recorded during the dry season. The rainy season starts April and ends in October with a peak in June and July while dry season is usually accompanied by a dry cold harmattan period which prevails during the month of December and January (FDALR, 1985). The soils are derived from coastal plain sands of sedimentary origin and are highly weathered and dominated by low activity of clay minerals (Akamigbo, 2010). The native tropical rainforest vegetation has been almost completely replaced by secondary forest of predominantly wild oil palm trees of various densities of coverage, and woody shrubs as chromolaenu odorata (Siam weed) and various grass under-growth. The land use patterns in the area are dominantly the fallow and continuous cropping systems and the major food crops grown are cassava, yam, maize and vegetables.

Soil samples were collected from four different land use patterns; 2-years continuously cultivated cassava farmland, 15 years' oil palm plantation, 2 years' pineapple orchards and 2 years fallowed land (secondary forest). The samples were collected using systematic random sampling from each of the land use pattern. Soil auger was used to collect soil samples from each of the land use pattern at three (3) different depths, $0-15 \mathrm{~cm}, 15-30 \mathrm{~cm}$ and $30-45 \mathrm{~cm}$. The samples from each land use at different depths were composited, mixed thoroughly and sub-sampled. The soil samples collected were stored in sampling bags for onward laboratory analysis.

\section{Laboratory Analysis}

Soil samples collected were air-dried, sieved with a $2 \mathrm{~mm}$ sieve. Particle size analysis was determined using the Bouyoucous hydrometer method (Gee and Or, 2002). Bulk density was determined by the core method (Grossman and Reinsch, 2002). Total nitrogen was determined by Micro-kjeldah digestion technique method (Bremner, 1996). Exchangeable bases were determined by the neutral ammonium acetate procedure buffered at $\mathrm{pH} 7.0$ (Thomas, 1982). Total carbon was analyzed by wet digestion (Nelson and Sommers, 1982). Available phosphorus was determined by Bray II method according to the procedure of (Olsen and Sommers, 1982). Total porosity $(\mathrm{Po})$ was obtained from bulk density $(\ell \mathrm{p})$ values with assumed particle density $(\ell \mathrm{s}) 2.65 \mathrm{gcm}^{-3}$ as follows, porosity $(\mathrm{Po})=100-(\ell \mathrm{p} / \ell \mathrm{s}) \times 100 / 1$. The Exchangeable cations were determined by the method described by Bremner and Mulvancy (1982). The amount of K and Na were determined using flame photometer with appropriate filters while $\mathrm{Mg}$ and $\mathrm{Ca}$ were determined by Atomic Absorption Spectrometer (AAS).

\section{Journal of the Faculty of Agriculture and Veterinary Medicine, Imo State University Owerri} website: www ajol.info 


\section{Data Analysis}

Soil data were subjected to descriptive statistics such as mean, standard deviation and coefficient of variation $(\mathrm{CV})$.

\section{RESULTS AND DISCUSSION}

The results of soil physical properties are shown in table 1. Particle size distribution was dominated by the sand fractions. The result of the coefficient of variation (Table 1.2) showed that sand fraction had low variation across the different land use types and ranged from $7 \%$ to $8 \%$. Texture of the surface soils was generally loam sand and sandy clay loam in the subsoil exception of pineapple orchard with sandy loam topsoil over sandy clay loam subsoil. The high percentage sand observed in all the land use patterns could be attributed to the geology of the area. The geology of the area is coasted plain sands which are characterized by sandy soils over a wide expanse of land (Akamigbo and Ukaegbu, 2003). The silt clay ratio (SCR) ranged from $0-$ $10-0.30,0.08-0.36,0.07-0.30$ and $0.06-0.20$ in land use types of oil palm plantation, (OPP), pineapple orchard (PO), cassava farmland (CF) and forest (F) respectively. The values of SCR of the studied land use types are in line with the findings of (Hassan et al., 2016) which states that the SCR of less than one (1) indicated that the soils are highly weathered and pedologically ferralitic in nature. Bulk density ranged from $1.61-1.77 \mathrm{~g} / \mathrm{cm}^{3}$ for oil palm plantation, $1.34-1.58 \mathrm{~g} / \mathrm{cm}^{3}$, pineapple orchard, $1.42-1.54 \mathrm{~g} / \mathrm{cm}^{3}$ cassava cultivated land and $1.48-1.61 \mathrm{~g} / \mathrm{cm}^{3}$ in fallow land use system. The mean values showed that oil palm plantation had the highest bulk density among the land use patterns studied. The bulk density result is in line with the findings of (Olivere and Merwin; 2001; Osuji et al; 2011 on soils of South Eastern Nigeria. Water holding capacity (WHC) ranged from $9.67-11.25 \%$ in oil palm plantation, 10.88 $-12.87 \%$ in pineapple orchard, $13.15-14.12 \%$ in cassava cultivated land in $11.33-13.02 \%$ in fallow land use type. The mean values of the water holding capacity indicated that cassava cultivated land had the highest (13.64) while the oil palm had the least (10.59\%). It increased in an irregular pattern with the soil depth in all land use types. The high value of WHC of the cassava cultivated land could be associated with the poorly drained nature of the soil, which can be corrected with a suitable drainage system. The difference in water holding capacity among the land use types is dependent on textural class, land use system, soil structure and vegetation. The findings are in line with that of (Brady and Weil, 2007), which states that soil physical properties and soil quality influence the soil water holding capacity.

\section{Soil Chemical Properties under different land use Types}

The result of the soil chemical properties (Table 3) indicated that the studied land use types were generally acidic. The mean values of soils $\mathrm{pH}$ of the land use patterns of pineapple orchard (4.67) cassava cultivated land (5.35) and oil palm plantation (5.11) were strongly acidic while the land use type for fallow land (5.40) was moderately acidic. The acidic rating was according to FDALR (1985) ratings. The acidic conditions of various land use types could be attributed to severe leaching by the high tropical rainfall (IITA, 1995, Ojanuga and Lekwa, 2005). The 
organic carbon of the studied land use systems had mean ranged $(1.11 \%, 1.45 \%, 0.68 \%$ and $1.56 \%$ ) for oil palm plantation, pineapple orchard land, cassava cultivated land and fallow land respectively. The O.C content of the studied land use systems were low when compared with the ratings (<4\%) of FDALR (1985).

The result of the findings reflects that organic carbon level of the studied land use types under the different land uses agreed with the findings of Ufot et al., (2016) of soils under vegetative cover in southeastern Nigeria. The high variation recorded in TN could be as a result of high accumulation of organic material on the surface horizon, rate of decomposition and rate of eluviations and illuviation process. The findings conform to the report of other researchers (Hassan et al., Chude et al., 2011; Ufot et al., 2016) in soils of similar agro-ecology. The studied land use systems had total nitrogen mean ranged $(0.11 \%, 0.13 \%, 0.07 \%$ and 0.16$)$ for oil palm plantation, pineapple orchard, cassava cultivated land and fallow land, respectively. The mean values of T.N in all land use types were below critical value of $(0.15 \%)$ for soils of Nigeria (FDALR, 1985, Chude et al., 2011). Low $\mathrm{N}$ values of the soils could be due to the rapid mineralization of soil organic matter, intense leaching due to high tropical rainfall (Howeler, 2002; Ojanuga and Lekwa, 2005). The available phosphorus had mean values of $1.33 \mathrm{mg} / \mathrm{kg}$, $9.45 \mathrm{mg} / \mathrm{kg}, 4.76 \mathrm{mg} / \mathrm{kg}$ and $8.88 \mathrm{mg} / \mathrm{kg}$ for land use types of cassava cultivated land, fallow land, oil palm plantation and pineapple orchard respectively. The available phosphorus in all the land use systems studied were low with the rating $(<6,<5)$ of FDALR $(1985)$. The low value of available phosphorus could be due to high sorption reaction. The causes of low available phosphorus have been attributed to high weathering of the soils, clay type, intense leaching, rainfall and absorption reaction by soil constituents (Hillocks, 2002). Also impacts of fixation and erosion can lead to decline of available $\mathrm{P}$. The available phosphorus under various land use patterns showed an increasing trend with increase in soil organic matter and cation exchangeable capacity.

Exchangeable bases values showed that Sodium $(\mathrm{Na})$ and Potassium $(\mathrm{K})$ were low compared to Calcium $(\mathrm{Ca})$ and Magnesium $(\mathrm{Mg}$ ) contents. The mean values of $\mathrm{Ca}, \mathrm{Mg}, \mathrm{K}$, and $\mathrm{Na}$ are indicated respectively $(2.14 \mathrm{cmol} / \mathrm{kg}, 2.01 \mathrm{cmol} / \mathrm{kg}, 0.23 \mathrm{cmol} / \mathrm{kg}$ and $0.16 \mathrm{cmol} / \mathrm{kg})$ for land use type of oil palm, $(2.62 \mathrm{cmol} / \mathrm{kg}, 2.32 \mathrm{cmol} / \mathrm{kg}, 0.22 \mathrm{cmol} / \mathrm{kg}$ and $0.13 \mathrm{cmol} / \mathrm{kg})$, for pineapple orchard $(1.61 \mathrm{cmol} / \mathrm{kg}, 1.52 \mathrm{cmol} / \mathrm{kg}, 1.46 \mathrm{cmol} / \mathrm{kg}$ and $0.10 \mathrm{cmol} / \mathrm{kg})$ for cassava cultivated land and $(2.12 \mathrm{cmol} / \mathrm{kg}, 1.73 \mathrm{cmol} / \mathrm{kg}, 0.21 \mathrm{cmol} / \mathrm{kg}$ and $0.17 \mathrm{cmol} / \mathrm{kg})$ for fallow land use type. The rating according to (FDALR, 1985) indicated that $\mathrm{Ca}, \mathrm{K}$ and $\mathrm{Na}$ were very low to low in the studied land use types, while $\mathrm{Mg}$ was moderate in all the land use systems. The low values in basic cations could be attributed to the type of parent material, high rainfall, erosion, and leaching (Chude et al., 2011). The cation exchange capacity had mean values of $5.48 \mathrm{cmol} / \mathrm{kg}$, $6.13 \mathrm{cmol} / \mathrm{kg}, 4.22 \mathrm{cmol} / \mathrm{kg}$ and $5.28 \mathrm{cmol} / \mathrm{kg}$ for land use systems of oil palm plantation, pineapple orchard, cassava cultivated land and fallow land respectively. The low amount of CEC in the land types could be attributed to low organic matter and high weathering (Akamigbo and

\section{Journal of the Faculty of Agriculture and Veterinary Medicine, Imo State University Owerri} website: www ajol.info 
Asadu, 1983). The CEC had an irregular pattern of increase with the soil depth in all the land use types.

The result of the soil chemical properties under different land use types indicated that the percentage base saturation (\%BS) showed the range of (82.06-84.30\%), (84.32-87.68\%), (75.33$85.36 \%),(77.70-80.34 \%)$ for oil palm plantation, pineapple orchard, cassava cultivated land and fallow land use system respectively. The percentage base saturation mean, indicated that fallow land use pattern is high while the oil palm plantation, pineapple orchard and cassava cultivated land are high according to the ratings of FDALR (1985). The result of the \%BS indicates that basic cation dominates the cation exchange capacity in all the land use types. The mean values showed that pineapple orchard land use type recorded the highest $(87.68 \%)$ and the fallow land use system, the least $(80.34 \%)$ among the land use types. The findings on percentage base saturation of the studied land use systems are contrary to the work of Igbokwe (1990) on soil fertility and land use patterns in eastern states of Nigeria. However, parent material, rate of weathering and global climate change could have contributed to the variation as reported by the findings of (Onweremadu et al., 2011, Wang et al., 2001).

\section{CONCLUSION}

In conclusion, land use types influence soil properties. The particle size distribution revealed that sand fraction dominated other fractions of the soil separate across the four land use types studied. Bulk density was high in palm plantation when compared with other land use types. The organic carbon and total nitrogen were generally low in all the land use types. Exchangeable cations and cation exchange capacity varied inconsistently and decreased down the horizons. It is suggested therefore that farmers should substitute fallow land use with Agroforestry and Alley farming so as to encourage litter or organic matter accumulation. The introduction of mixture of leguminous creepers likes clitoria spp, desmodium, glacillis and in addition farmers may periodically fallow their lands to sequester organic matter, stabilize soil aggregates, improves nutrient cycles for sustainable agricultural production. 


\section{REFERENCES}

Akamigbo, F.O.R. (2010). Fundamental Methods of Soil Resources Survey, Classification, Interpretation and Application, University of Nsukka Press, Nigeria, Pp. 81 - 83.

Akamigbo, F.O.R., and Ukaegbu, C.E., (2003). The Rule of Soil Conservation in Nigeria, Agriculture in $21^{\text {st }}$ Century. Invited paper to USDA Workshop, NRCRI UmudikeUmuahia.

Alves, S.O., (2002). Survey of Fertility Status of some Soils in Ondo State under Traditional Cultivation. Journal of Agriculture 1 (2) 134-149.

Badalikova, B. and Hruby, J. (2016). Influence of land use types on soil fertility status of Montance Grassland, New Zealand. Journal of plant ad soil. 176:255-265.

Brady, N.C, Weil, R.R (2007). The Nature and Properties of Soil $14^{\text {th }}$ Edition. Macmillan Publisher, New York, pp. 243-244.

Bremner, J.M. (1996). Total Nitrogen. Sparks, D.L. (ed) Methods of Soil analysis: Parts, Chemical Methods. $2^{\text {nd }}$ ed, SSSA book series No. 5, SSSA, Madison, Wl, 1085-1125.

Bremner, J.M., and Mulvancy, F.S., (1982). Nitrogen- Total in D.L. Sparks, (ed) Methods of Soil Analysis: Part 3. SSSA Book Series No. 5, Madison, U.S.A 1085-1122.

Chude, V.O., Olay, Wola, S.O. and C.K. Daudu (2011). Fertilizer use and management $\left(4^{\text {th }}\right.$ edition) Federal Fertilizer Department, Federal Ministry of Agriculture and Rural Development, pp. 214-215.

Donahue, E., Miller, W. and Shicklune C. (1990). An Introduction to Soil and Plant Growth. $3^{\text {rd }}$ Edition, Oxford University Press, London, pp. $70-75$.

Federal College of Land Resources Technology (FECOLART) (2012). Soil Survey and Land Evaluation of some Local Government Area in Imo State. Pp. 20 - 25.

Food and Agriculture Organization (FAO) (2016). A Framework for Fertility Land Evaluation. FAO Bulletin 92, FAO/UNESCO, France.

Gee, G.W. and Or, D., (2002). Particle size analysis. In: Dane, J.H., Topp, G.C. (eds). Methods of Soil analysis part 4, physical methods. Soil Science Society Am. Book Series; No. 5 ASA and SSSA Madison vol. 1, pp. 255-295.

Grossman, R.B and Reinsch, T.G. (2002). Bulk density and Linear extensibility. In methods of Soil analysis, Part 4 physical methods. Book series No. 5, ASA and SSA Madison, Wl, pp. $201-228$.

Hassan, A.M., Voncur, N. Amba. A.A. Murabbi, A., and Marvelous, T.A. (2016). Fertility Status under different land use systems of selected soils developed on Basement Complex

Journal of the Faculty of Agriculture and Veterinary Medicine, Imo State University Owerri website: www ajol.info 
Bauchi Metropolis. Proceedings of the $40^{\text {th }}$ Annual Conf. SSN University of Calabar, Calabar, pp. $61-69$.

Hillocks, M.C., (2002). Effects of Nutrient Application and Aeration in Degraded Compacted Soil. Journal of Soil Science and Environment 3(2) 235 - 240.

Howeler, S.O. (2002). Evaluation of Fertility Status of Acid Sands of Eastern Nigeria. Soil Sci. Journal. of Nigeria. Vol. (1) 121 - 124.

International Institute of Tropical Agriculture (IITA) (1995). Cassava in Tropical Africa A Reference Manual, IITA, Ibadan, pp. 25 - 31.

Nelson, D.W. and Sommers, L.E (1982). Total Organic carbon, organic matter. In: Pages, A.L., Miller R.H and Kenney, D.R. (Eds). Methods of Soil Analysis: part 2 Ameri. Soc. Agron., Madison, Wis,. pp.539-579.

Nsokpo, E.E., Ibanga, J.E. (2001). Fertility Status of selected Hydromorphic soils, Akamkpa L.G.A. Cross Rivers State, Proceedings $2^{\text {nd }}$ Ann,. Conf. SSSN, UNCAL- Calabar. Pp. $160-165$.

Ojanuga, A.G. Lekwa, G., (2005). Survey Classification and Genesis of Acid Sands. Plenary paper presented, Ann. Conf. SSSN, Owerri.

Olson, S.R. and Sommers, L.E., (1982). Phosphorus in: Method of Soil Analysis. A.L. Page, R.H. Miller and D.R. Kenney (eds). Madison, WI. American Society of Agronomy. 1572 pp.

Osuji, G.E., Okon, M.A, Chukwuna M.C., and I.C. Nwarie (2011). Physico-chemical characteristics of soils under selected land use practices in Owerri, Southeastern Nigeria. World Journal of Agricultural Science 6(30) 322 - 326.

Ufot, U. O, Iren, O. B and Chikere-Njoku. C., (2016). Effects of Land use on soil physical and chemical properties in Akokwa Area of Imo State, Nigeria International Journal of Life Science and Scientific Resources 2(3) 273-278. 
Volume 17 Number 2, October 2019 pp 1- 13

APPENDIXES

Table 1: Physical Properties of the Various Land Use Types

\begin{tabular}{|c|c|c|c|c|c|c|c|c|c|}
\hline Land use type & $\begin{array}{l}\text { Dept. } \\
(\mathrm{Cm})\end{array}$ & Sand & $\begin{array}{l}\text { C:14 } \\
\text { n/kn }\end{array}$ & Clay & TC & SCR & $\begin{array}{l}\text { BD } \\
\left(\mathrm{g} / \mathrm{cm}^{3}\right)\end{array}$ & $\begin{array}{l}\text { TP } \\
(\%)\end{array}$ & $\begin{array}{l}\text { WHC } \\
(\%)\end{array}$ \\
\hline Oil Palm & $0-15$ & 827 & 40 & 133 & LS & 0.30 & 1.77 & 34.01 & 9.67 \\
\hline plantation & $15-30$ & 787 & 20 & 193 & SL & 0.10 & 1.67 & 37.03 & 11.28 \\
\hline (15 yrs) & $30-45$ & 747 & 20 & 213 & SCL & 0.20 & 1.61 & 39.27 & 10.83 \\
\hline Mean & & 787 & 33.3 & 179.6 & & 0.20 & 1.68 & 36.77 & 10.59 \\
\hline Pineapple & $0-15$ & 849 & 40 & 111 & LS & 0.36 & 1.53 & 11.55 & 11.35 \\
\hline Orchard & $15-30$ & 789 & 20 & 191 & SL & 0.10 & 1.34 & 48.33 & 12.97 \\
\hline$(2 \mathrm{yrs})$ & $30-45$ & 927 & 20 & 253 & SCL & 0.08 & 1.58 & 39.73 & 10.88 \\
\hline Mean & & 788.3 & 26.6 & 185.0 & & 0.18 & 1.48 & 33.20 & 11.73 \\
\hline Cassava & $0-15$ & 827 & 40 & 133 & LS & 0.30 & 1.42 & 45.47 & 13.15 \\
\hline Cultivated & $15-30$ & 748 & 20 & 232 & SL & 0.10 & 1.54 & 41.14 & 13.66 \\
\hline land (2 yrs) & $30-45$ & 689 & 20 & 290 & SCL & 0.07 & 1.49 & 40.01 & 14.12 \\
\hline Mean & & 754.7 & 26.6 & 219.3 & & 0.16 & 1.48 & 42.20 & 13.64 \\
\hline Fallow land & $0-15$ & 769 & 40 & 191 & LS & 0.20 & 1.45 & 44.51 & 11.33 \\
\hline \multirow[t]{2}{*}{$(2 \mathrm{yrs})$} & $15-30$ & 728 & 20 & 252 & SL & 0.08 & 1.61 & 41.12 & 11.39 \\
\hline & $30-45$ & 667 & 20 & 313 & SCL & 0.06 & 1.48 & 43.65 & 13.02 \\
\hline Mean & & 721.3 & 26.6 & 252 & & 0.11 & 1.51 & 43.09 & 11.91 \\
\hline
\end{tabular}

$\mathrm{TC}=$ Textural Class, $\mathrm{LS}=$ Loamy Sand, $\mathrm{SL}=$ Sandy loam $=\mathrm{SCL}=$ Sandy Clay Loam, $\mathrm{SCR}=$ Silt clay ratio, $\mathrm{BD}=$ Bulk Density, $\mathrm{TP}=$ Total Porosity, $\mathrm{WHC}=$ Water Holding Capacity

Journal of the Faculty of Agriculture and Veterinary Medicine, Imo State University Owerri website: www ajol.info 
Journal of Agriculture and Food Sciences

Chikere-Njoku C.

Volume 17 Number 2, October 2019 pp 1-13.

Table 2: Coefficient of Variation among Soil Physical Properties under Land Use

\begin{tabular}{|c|c|c|c|c|c|c|c|c|}
\hline Land use type & $\begin{array}{l}\text { Statistical } \\
\text { Tool }\end{array}$ & $\begin{array}{r}\text { Sand } \\
\mathrm{g} / \mathrm{kg}\end{array}$ & $\begin{array}{l}\text { Silt } \\
\text { g/kg }\end{array}$ & Clay & SCR & $\begin{array}{l}\text { BD } \\
\left(\mathrm{g} / \mathrm{cm}^{3}\right)\end{array}$ & $\begin{array}{l}\text { TP } \\
(\%)\end{array}$ & $\begin{array}{l}\text { WHC } \\
(\%)\end{array}$ \\
\hline & Mean & 787 & 33.3 & 179.6 & 0.20 & 1.68 & 36.77 & 10.59 \\
\hline Oil Palm & $\mathrm{CV}$ & 8 & 36.89 & 22.77 & 60.03 & 5.01 & 8.79 & 6.88 \\
\hline \multirow{2}{*}{$\begin{array}{l}\text { plantation } \\
\text { (15 yrs) }\end{array}$} & Ranking & LV & HV & MV & $\mathrm{HV}$ & IV & LV & LV \\
\hline & Mean & 788 & 26.6 & 185.0 & 0.18 & 1.48 & 33.20 & 11.73 \\
\hline Pineapple & $\mathrm{CV}$ & 8 & 35.07 & 23.99 & 40.73 & 4.07 & 6.63 & 6.98 \\
\hline Orchard & Ranking & LV & $\mathrm{HV}$ & MV & HV & LV & LV & LV \\
\hline \multirow[t]{2}{*}{$(2 \mathrm{yrs})$} & $30-45$ & 927 & 20 & 253 & 0.08 & 1.58 & 39.73 & 10.88 \\
\hline & Mean & 754.7 & 26.6 & 219.3 & 0.16 & 1.48 & 42.20 & 13.64 \\
\hline Cassava & $\mathrm{CV}$ & 7 & 35.07 & 24.32 & 38.24 & 4.07 & 4.84 & 20.68 \\
\hline \multirow{2}{*}{$\begin{array}{l}\text { Cultivated } \\
\text { land ( } 2 \text { yrs) }\end{array}$} & Ranking & LV & $\mathrm{HV}$ & MV & HV & LV & LV & MV \\
\hline & Mean & 721.3 & 26.6 & 252 & 0.11 & 1.51 & 43.09 & 11.91 \\
\hline \multirow{2}{*}{$\begin{array}{l}\text { Fallow } \\
\text { land (2yrs) }\end{array}$} & $\mathrm{CV}$ & & 35.07 & & & 4.93 & 4.87 & 6.99 \\
\hline & Ranking & & $\mathrm{HV}$ & & & LV & LV & LV \\
\hline
\end{tabular}

$\mathrm{SCR}=$ Silt clay ratio, $\mathrm{BD}=$ Bulk Density, $\mathrm{WHC}=$ Water Holding Capacity

$\mathrm{CV}=$ Coefficient of Variation, $\mathrm{LV}=$ Low Variability $<15 \mathrm{~T}, \mathrm{MV}=$ Moderate Variability $<35$, $\mathrm{HV}=$ High Variability $>35$.

Journal of the Faculty of Agriculture and Veterinary Medicine, Imo State University Owerri website: www ajol.info 
Journal of Agriculture and Food Sciences

Volume 17 Number 2, October 2019 pp 1- 13

Table 3: Chemical Properties of the Soil under Land Use Types

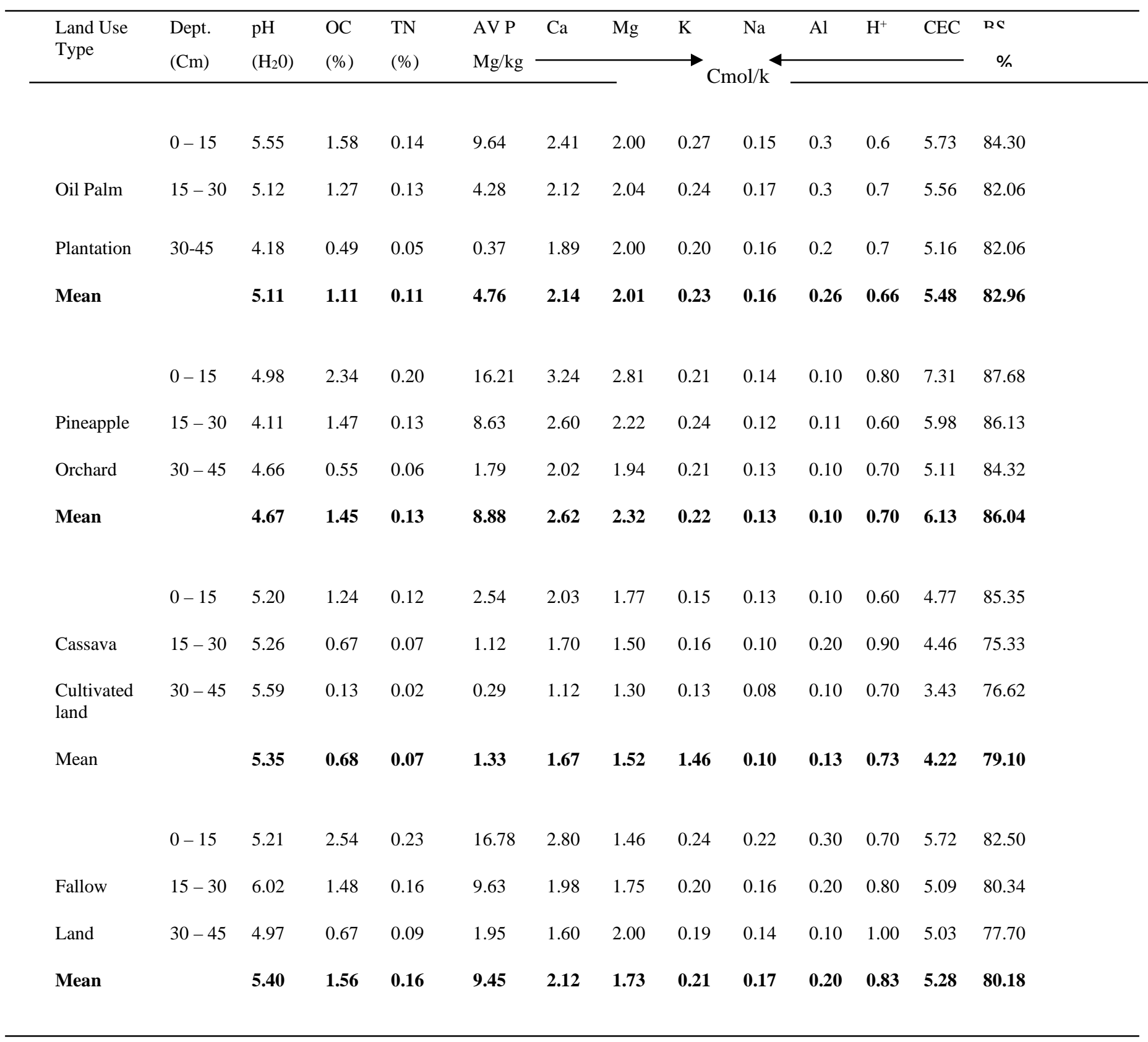

$\mathrm{OC}=$ Organic Carbon, Organic Matter $=\mathrm{OC} \times 1.724, \mathrm{TN}=$ Total Nitrogen, $\mathrm{AV}=$ Available Phosphorus, $\mathrm{CEC}=$ Cation Exchange Capacity, BS = Base Saturation, Conversion Factor from (percentage OC, TN Sand, Silt, Clay) to $\mathrm{g} / \mathrm{kg}=$ Multiply by 10 .

Journal of the Faculty of Agriculture and Veterinary Medicine, Imo State University Owerri website: $w$ ww ajol.info 
Journal of Agriculture and Food Sciences

Volume 17 Number 2, October 2019 pp 1- 13

Table 4: Coefficient of Variation among Soil Chemical Properties under Land Use Types

$\begin{array}{lllllllllllllllll}\text { Land Use } & \text { Dept. } & \mathrm{pH} & \mathrm{OC} & \mathrm{TN} & \mathrm{AV} . \mathrm{P} & \mathrm{Ca} & \mathrm{Mg} & \mathrm{K} & \mathrm{Na} & \mathrm{Al} & \mathrm{H}^{+} & \mathrm{CEC} & \mathrm{BS}\end{array}$

Type

$$
(\mathrm{Cm}) \quad\left(\mathrm{H}_{2} \mathrm{O}\right) \quad(\%) \quad(\%) \quad \mathrm{Mg} / \mathrm{kg}
$$

$\mathrm{Cmol} / \mathrm{kg}$

$\begin{array}{lllllllllllll}\text { Mean } & 5.11 & 1.11 & 0.11 & 4.76 & 2.14 & 2.01 & 0.23 & 0.16 & 0.26 & 0.66 & 5.48 & 82.96\end{array}$

$\begin{array}{llllllllllllll}\text { Oil Palm } & \text { CV } & 3.82 & 85.67 & 90.06 & 189.77 & 8.75 & 13.86 & 19.77 & 8.84 & 36.77 & 21.77 & 7.73 & 4.98 \\ \text { Plantation } & \text { Ranking } & \text { LV } & \text { HV } & \text { HV } & \text { HV } & \text { LV } & \text { MV } & \text { MV } & \text { LV } & \text { HV } & \text { MV } & \text { LV } & \text { LV }\end{array}$

$\begin{array}{lllllllllllll}\text { Mean } & 5.03 & 1.45 & 0.13 & 8.88 & 2.62 & 2.32 & 0.22 & 0.13 & 0.10 & 0.70 & 6.13 & 86.04\end{array}$

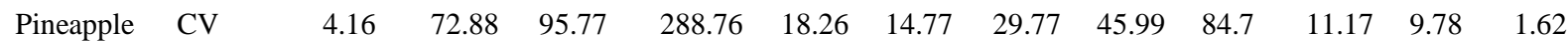

$\begin{array}{llllllllllllll}\text { Orchard } & \text { Ranking } & \text { LV } & \text { HV } & \text { HV } & \text { HV } & \text { MV } & \text { MV } & \text { HV } & \text { LV } & \text { HV } & \text { LV } & \text { LV } & \text { LV }\end{array}$

$\begin{array}{lllllllllllll}\text { Mean } & 5.35 & 0.68 & 0.07 & 1.33 & 1.61 & 1.52 & 1.46 & 0.10 & 0.13 & 0.73 & 4.22 & 79.10\end{array}$

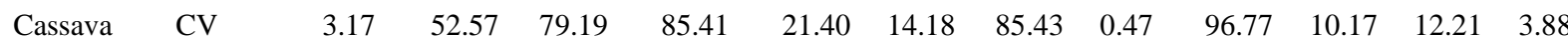

$\begin{array}{llllllllllllll}\text { Cultivated } & \text { Ranking } & \text { LV } & \text { HV } & \text { HV } & \text { HV } & \text { MV } & \text { MV } & \text { HV } & \text { LV } & \text { HV } & \text { LV } & \text { LV } & \text { LV }\end{array}$

Land

\begin{tabular}{llllllllllllll} 
& Mean & $\mathbf{5 . 4 0}$ & $\mathbf{1 . 5 6}$ & $\mathbf{0 . 1 6}$ & $\mathbf{9 . 4 5}$ & $\mathbf{2 . 1 2}$ & $\mathbf{1 . 7 3}$ & $\mathbf{0 . 2 1}$ & $\mathbf{0 . 1 7}$ & $\mathbf{0 . 2 0}$ & $\mathbf{0 . 8 3}$ & $\mathbf{5 . 2 8}$ & $\mathbf{8 0 . 1 8}$ \\
Fallow & CV & 2.82 & 88.77 & 106.87 & 298.77 & 18.77 & 19.44 & 18.99 & 9.77 & 28.66 & 17.28 & 8.77 & 4.70 \\
Land & Ranking & LV & HV & HV & HV & MV & MV & MV & LV & HV & MV & LV & LV \\
\hline
\end{tabular}

$\mathrm{OC}=$ Organic Carbon, $\mathrm{TN}=$ Total Nitrogen, $\mathrm{AV}=$ Available Phosphorus, $\mathrm{CEC}=$ Cation Exchange Capacity, BS = Base Saturation, CV $=$ Coefficient of variation, $<15=$ low variability $(\mathrm{LV}), \geq 15<35=$ Moderate Variability (MV), $>35=$ High variability (HV).

Journal of the Faculty of Agriculture and Veterinary Medicine, Imo State University Owerri website: www ajol.info 
Journal of Agriculture and Food Sciences

Chikere-Njoku C. $^{13}$

Volume 17 Number 2, October 2019 pp 1- 13

Table 5: Correlation Matric of the Studied Soil Properties

\begin{tabular}{|c|c|c|c|c|c|c|c|c|c|c|c|c|c|c|}
\hline & Sand & Silt & Clay & SCR & BD & WHC & TP & $\begin{array}{l}\text { pH } \\
\left(\mathbf{H}_{2} \mathbf{0}\right)\end{array}$ & $\begin{array}{l}\text { pH } \\
\text { (kcl) }\end{array}$ & OC & $\mathbf{T N}$ & AVP & CEC & BS \\
\hline Sand & 1 & & & & & & & & & & & & & \\
\hline Silt & 0.042 & 1 & & & & & & & & & & & & \\
\hline Clay & $-0.985^{* *}$ & -0.193 & 1 & & & & & & & & & & & \\
\hline SCR & $0.659^{* *}$ & $0.725^{* *}$ & $-0.763^{* *}$ & 1 & & & & & & & & & & \\
\hline $\mathrm{BD}$ & -0.070 & 0.180 & 0.060 & 0.036 & 1 & & & & & & & & & \\
\hline WHC & -0.275 & -0.247 & 0.317 & -0.340 & -0.316 & 1 & & & & & & & & \\
\hline TP & -0.330 & -0.260 & 0.358 & $-0.500^{*}$ & $-0.510^{*}$ & 0.315 & 1 & & & & & & & \\
\hline $\mathrm{pH}\left(\mathrm{H}_{2} \mathrm{O}\right.$ & -0.057 & 0.015 & 0.058 & -0.114 & $0.553^{*}$ & -0.324 & 0.190 & 1 & & & & & & \\
\hline $\mathrm{pH}(\mathrm{KCL}$ & $0.569^{* *}$ & 0.095 & $-0.562^{* *}$ & 0.351 & $0.579^{* * *}$ & -0.317 & $-0.433^{*}$ & 0.471 & 1 & & & & & \\
\hline $\mathrm{OC}$ & $0.785^{* *}$ & 0.087 & $-0.784 * *$ & $0.619^{* *}$ & -0.290 & -0.298 & -0.352 & -0.269 & 0.178 & 1 & & & & \\
\hline $\mathrm{TN}$ & $0.794^{* *}$ & 0.082 & $-0.792 * *$ & $0.616^{* *}$ & -0.298 & -0.308 & -0.345 & -0.271 & 0.173 & $0.998^{* *}$ & 1 & & & \\
\hline Av. P & 0.735 & 0.112 & $-0.743^{* *}$ & $0.636^{* *}$ & -0.150 & -0.273 & $-0.557^{* *}$ & -0.240 & 0.319 & $0.910^{* *}$ & $0.903^{*}$ & 1 & & \\
\hline CEC & 0.288 & $0.430^{*}$ & -0.347 & $0.493^{*}$ & 0.086 & $-0.450^{*}$ & $-0.515^{*}$ & 0.057 & 0.218 & $0.528^{* *}$ & $\begin{array}{l}0.537^{*} \\
*\end{array}$ & $0.595^{* *}$ & 1 & \\
\hline BS & $0.440^{*}$ & 0.147 & $-0.443^{*}$ & 0.381 & 0.009 & -0.100 & -0.277 & -0.176 & 0.259 & $0.426^{*}$ & $0.432^{*}$ & $0.440^{*}$ & $\begin{array}{l}0 . \\
50 \\
5^{*}\end{array}$ & 1 \\
\hline
\end{tabular}

SCR = Silt Clay Ratio, BD = Bulk Density, WHC = Water Holding Capacity, $\mathrm{TP}=$ Total Porosity, $\mathrm{OC}=$ Organic Carbon, $\mathrm{TN}=$ Total Nitrogen, Av. $\mathrm{P}=$ Available Phosphorus, $\mathrm{CEC}=$ Cation Exchange Capacity, BS = Base Saturation

Journal of the Faculty of Agriculture and Veterinary Medicine, Imo State University Owerri website: www ajol.info 